\title{
Outside the European Economic and Monetary Union: Consequences for the United Kingdom
}

\author{
Anna Konarzewska
}

\section{Abstract}

The consequences of staying outside the European Economic and Monetary Union can be divided into three categories: political, economic, and social. For the United Kingdom, most attention has been concentrated on the issue of economic gains and losses. The potential gains include a possibility for the British government to conduct its own national economic and monetary policy, the elimination of so-called social dumping, preserving the British mortgage and housing markets, and promoting London as a worldwide financial center. Moreover, approving the Euro could enlarge British foreign trade and enhance inflows of foreign direct investment. On the other hand, the negative economic consequences focus on lack of transparency of prices, no elimination of transaction costs, and the risk of disrupting the exchange rate of the pound sterling. The political and social consequences of staying outside the Euro zone must also be taken into account when analyzing the British case. Without participating in the common currency, the United Kingdom could preserve her national sovereignty and independence, although this remains questionable in the current world, which is characterized by high levels of interdependence. Likewise, the British stand to lose their influence in the European Union and in the world by not participating in the third stage of the EMU.

Keywords: United Kingdom, EMU, Euro, Monetary Policy, Financial Center, Mortgage Market, Sovereignty

Remaining outside the "Euro zone"- the area where the common currency approved by a majority of the EU member states is the legal tender - the United Kingdom of Great Britain and Northern Ireland has found herself in a completely different political and socio-economic situation. The common currency, and the heightened levels of economic and monetary cooperation that it entails, bring many benefits - for example, a reduction of transaction costs and a diminution of the risks associated with the existence of a floating exchange rate. However, a nation's decision on whether or not to become a member of the currency union is based, according to G. S. Tavlas, mostly on political calculations related to the advantages and disadvantages of a membership in such a union. ${ }^{1}$ The consequences of staying apart from the European project can be analyzed according to their positive and

* Anna Konarzewska is main security expert in the National Security Bureau of the Republic of Poland. She graduated from the Institute of International Relations (Warsaw University) and the Polish-French Programme for European Studies SGH-SciencesPo (Warsaw School of Economics). She has an MA diploma in international political and economic relations and in economics. She is a doctoral candidate at the International Security Department (Warsaw School of Economics).

1 George S. Tavlas, "Benefits and Costs of Entering the Eurozone," Cato Journal 24:1-2 (Spring/ Summer 2004): 89-106. 
negative aspects. The positive ones are usually related to those economic and financial profits that certain states might gain as a result of not adopting the common currency. On the other hand, the negative ones are concentrated on those benefits of participation in a currency union that are lost by countries that choose to opt out.

Thus, before the U.K. makes a decision on membership in the third stage of the European Economic and Monetary Union (EMU), it is necessary to discuss all the potential gains and losses connected with membership in the euro zone. It is a common statement that the losses are usually attached to macroeconomic concerns, while the gains accrue within the microeconomic sphere. Therefore, the main prerequisite for the creation of a currency union is demonstrating a superiority of microeconomic effectiveness over the macroeconomic costs, particularly those related to a nation's loss of its ability to control national macroeconomic policy. ${ }^{2}$ The immediate effects of entering the EMU would include removing the costs of currency conversion, decreased variation in currency exchange rates in the euro zone, and more transparent prices. Transaction costs remain the main obstacle in trade relations, because changes in exchange rates lead to situations where trade with foreign nations is very insecure. Furthermore, lack of transparency in prices could lower competitiveness, as well as discourage consumers and firms from buying needed products and services. On the other hand, it is worth mentioning that the elimination of floating exchange rates could facilitate production, enhance inflows of foreign direct investment (FDI), and in consequence could improve the level of economic growth. ${ }^{3}$ At this stage, the costs of joining a common currency include adjusting the national economy and national finances to function in a monetary union.

The mid-term consequences of adopting a common currency are connected with economies of scale, increased trade, and possible increases in FDI, while the long-term consequences could be characterized by an increase in competitiveness as well as better concentration and specialization of production. However, it must be stressed that the economic benefits to be gained from joining a currency union are rather modest. Moreover, it is very difficult to estimate the size of saved transaction costs in a monetary union. ${ }^{4}$

On the other hand, remaining on the sidelines for the third stage of the EMU could bring significant gains, including maintaining control over national monetary policy (because the national currency remains in place), which enables a country to function without any difficulty in case of an asymmetric economic shock. In addition, the national central bank has greater ability to influence levels of unemployment and inflation, whose increase could be problematic for the national economy. Hence, in a currency union, each member is obliged to conduct responsible budget and structural policies, which are aimed at mod-

2 Alan Ahearne and Jean Pisani-Ferry, "The Euro: Only for the Agile," Bruegel Policy Brief, no. 2006/01 (February 2006), 2.

3 Artur Gradziuk and Katarzyna Sochacka, "Zagadnienie integracji walutowej w Unii Europejskiej na przykładzie Danii, Szwecji i Wielkiej Brytanii,” Biuletyn PISM 70 (Warsaw, 2002).

4 Michele Fratianni and Jurgen von Hagen, The European Monetary System and European Monetary Union (Boulder, CO: Westview Press, 1992), 162. 
ernizing national economies and which help markets for products, services, and capital to function properly. ${ }^{5}$

It must be again underlined that the creation of a currency union is not only a technical decision-above all, it is a political matter. It is related to the fundamental question of national sovereignty, and could have an impact on the economic development of member states of the monetary union. ${ }^{6}$

\section{The United Kingdom}

The United Kingdom of Great Britain and Northern Ireland has supported the process of economic integration within the European Community, especially in terms of the introduction of a free trade area and the creation of a European common market. And these developments have brought significant profits for the British economy. However, the country remains outside the third stage of the Economic and Monetary Union, and so far has exercised a strong veto over merging the pound sterling with the euro. Opponents of the common currency believe that, after accepting the euro and elements of the common European socio-economic policy, Great Britain would cease to be a market economy and would be characterized by the low economic growth, higher unemployment, higher taxes, and larger public sector seen in many nations in continental Europe. ${ }^{7}$ It is necessary to point out four distinct lines of reasoning in the British attitude towards Europe and the process of European integration to help explain why the United Kingdom has not joined the Economic and Monetary Union. Those arguments are historical, geographical, political, and economic and socio-cultural in nature.

Remaining outside the most important undertaking in Europe after the Second World War has negative as well positive consequences (socio-economic as well as political) for the United Kingdom. The economic losses that Britain suffers from not participating in the EMU focus on decreased productivity and the diminished competitiveness of her economy on international markets, leading to lower quality of British goods. Second, if Britain accepted the common currency, changes in the exchange rates between European currencies would be eliminated, and exchange risks would be erased. Moreover, there would be no transaction costs, and more transparency in prices across the EU area would be guaranteed. Additionally, increased economic growth, improved currency liquidity, and higher returns on capital as well as enhanced inflow of FDI would be observed in the British Isles. The negative consequences are also political and social in nature. By not being part of the EMU, Britain has less influence on decisions made within the European Union, and fewer possibilities to present her own opinions in different cases, which makes the process of European integration extremely distant from the concerns and views of British citizens. On the other hand, the positive outcomes of not being a member of the EMU include the

5 Scott Salembier and Jakub Wtorek, Polityczno-ekonomiczne implikacje kalendarza przyjęcia wspólnej waluty euro przez nowe państwa członkowskie Unii Europejskiej, ed. A. Mayhew (Warsaw/Sussex: demosEuropa-Centrum Strategii Europejskiej, January 2007), 20-21.

6 Tomasso Padoa-Schioppa, The Road to Monetary Union in Europe: The Emperor, the Kings, and the Genies (Oxford: Oxford University Press, 2000), 107.

7 Neil Record, "Europe is Dragging Britain into the Mire," Financial Times (6 January 2005). 
possibility to conduct a proper national economic policy, protecting the position of the City of London in international financial relations (especially regarding offshore markets being now developed there), and bolstering the condition of the British housing market.

\section{Economic Consequences of Staying Outside the EMU}

The main consequences that are typically analyzed in regard to membership in the third stage of the Economic and Monetary Union are economic in nature. This group of consequences will be the first discussed in this essay. Later, I will also concentrate on the political and social implications of not being a member of the euro zone.

\section{Foreign Trade}

Great Britain is highly dependent on foreign trade. Indeed, international trade has been the foundation of Britain's prosperity for the last 200 years. Foreign trade in the U.K. is equivalent to 27 percent of Britain's GDP, compared to 21 percent in the OECD as a whole. Recently, significant increases in British trade relations with Europe have been observed, which is a strong argument for British participation in the EMU. In 1973, when the United Kingdom joined the European Community, only 35 percent of the goods and services exported by the U.K. went to continental Europe. By 2007, 59 percent of British exports went to the EU member states. By comparison, only 16 percent of total British trade is with the United States. ${ }^{8}$ One must bear in mind that separate national currencies are said to act as barriers to trade. Staying outside the EMU means that British firms exporting to the euro zone still face transaction costs compared to their continental competitors (e.g., Germany and France). Therefore, not being a member of the EMU has negative consequences for British trade. ${ }^{9}$ Tendencies in British exports and imports are shown in the tables below.

However, it should be stressed that the British economy has a very different structure of production from that which is present in continental Europe, one for which the common currency would have a negative impact. The United Kingdom-like the United States, but unlike any other EMU member state - is a significant oil producer. Moreover, the country has a particular competitive advantage in the high technology, aeronautical, pharmaceutical, biochemical, scientific instrumentation, and telecommunication sectors-sectors whose products, together with oil production, are typically priced in U.S. dollars. Great Britain has a higher ratio of high-tech production than France, Germany, and Italy. In the high-tech industries such as pharmaceuticals, where Britain has some of the world's largest and most efficient companies, success in research and development is far more significant than skill in manufacturing. The country has also managed to establish a large comparative advantage in the so-called "mid-tech" industries, where production skills are supreme, and it surpasses almost all other countries in original research, with far more Nobel Prizes than any country except the United States. Thus, the sterling-dollar exchange rate remains far more important to these key manufacturing segments of the British economy than the sterling-euro exchange rate.

See www.euro.gov.uk.

9 See www.hm-treasury.gov.uk. 
Great Britain

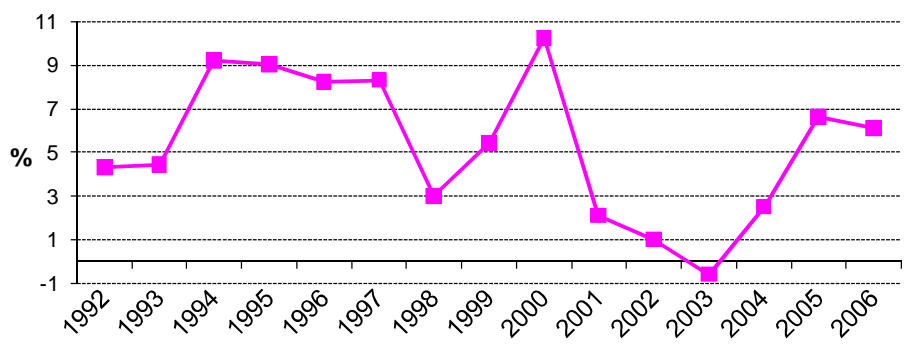

Figure 1: British Exports of Goods and Services to the Euro Zone at 1995 Prices (national currency; annual percentage change) ${ }^{10}$

\section{Great Britain}

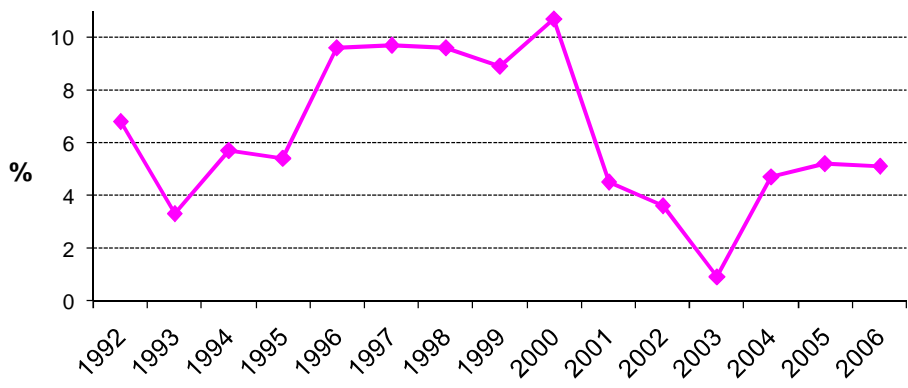

Figure 2: Import of Goods and Services at 1995 Prices (national currency; annual percentage change) ${ }^{11}$

EMU membership might increase exchange rate volatility for these crucial sectors of the British economy. It is often supposed that because almost 60 percent of British trade is with other EU member states, and only 16 percent is with the United States, the pound's exchange rate with the U.S. dollar matters little in relation to its exchange rates with France and Germany. What such calculations ignore is that, while the United Kingdom exports high-tech products to Europe, her principal competition within Europe will often come from U.S. and Japanese companies. In sum, with a different structure of production from continental Europe, Britain often needs a different combination of exchange rates,

${ }^{10}$ Data drawn from: European Commission, Directorate-General for Economic and Financial Affairs, "European Economy: The EU Economy, 2006," Doc. No. 5/2006; IMF, OECD.

11 Ibid. 
and the present flexibility of the sterling rate with regard to both the euro and the dollar delivers it. ${ }^{12}$

On the other side, the single currency could positively influence markets in the U.K. in three important ways: through cheaper transaction costs, exchange rate certainty, and more transparent price differences. The most obvious economic advantage connected with the disappearance of the currency borders is the elimination of transaction costs, a benefit that promotes competition within the European Union (and thus facilitates lower inflation) and brings advantages for consumers, who experience lower prices and thereby save more money for future investments. Moreover, with the rise of the euro, firms have started to differentiate their products more in terms of quality and innovation, and less on price. In consequence, companies are able to sell their products more widely and are able to profit from the economies of scale that are observed on the American market. ${ }^{13}$ Needless to say, when everyone uses the same unit of currency, it is easier to compare prices between countries. It must be stressed that some differences in prices are unavoidable arising from transport and information costs, but not all price differences can be attributed to these costs. Nowadays, on the European continent, significant differences in prices for different goods and services can be observed. The average price variation across Europe for a given good or service is 16 percent, which means that the scope of change in prices is approximately 40 percent larger than between various states and regions in the U.S. The price of a standard Volvo automobile, for instance, can differ by 15-20 percent between countries in Europe.

The common currency could change this situation for the better, and ultimately diminish prices in the British Isles, making them more comparable to the prices in continental Europe. ${ }^{14}$ Britain is generally a more expensive place to live than other European countries. London is said to be the second most expensive city in the European Union. Only Copenhagen, which is also outside the euro zone, is ranked higher with any frequency. Furthermore, the Economist Intelligence Unit's latest worldwide cost of living survey shows that London was the eighth most expensive city in the world, and the European Consumers' Association has shown that the United Kingdom is the most expensive country in Europe, particularly for popular consumer goods, with prices almost 30 percent higher than in Germany. ${ }^{15}$

The uncertainty of exchange rates deters the market from being unified, and discourages foreign businesses from investing in the U.K. The exchange rate of national currencies contributes to inflows of speculative capital and artificial increases in levels of interest rates in a country, causing periodic irrational fluctuations of the exchange rate of a na-

12 David Currie, "EMU: Threats and Opportunities for Companies and National Economies," in The Impact of the Euro, eds. Mark Baimbridge, Brian Burkitt, and Philip Whyman (London: Palgrave Macmillan, 2000), 143-44.

13 Europe's Response to EMU, $4^{\text {th }}$ Annual Report (London: KPMG Consulting, January 2000).

14 David Simon, "EMU and the Opportunities for British Business," in The Impact of the Euro, eds. Baimbridge, et al., 171

15 "Cost of living report," EDA-international, www.eda-international.com; "Worldwide Cost of Living," Economist Intelligence Unit, eiu.enumerate.com; European Consumers' Association, www.beuc.org. 
tional currency. As a result, the currency appears to appreciate, but the relevant macroeconomic indicators do not sustain it. ${ }^{16}$ Bearing this in mind, it must be stressed that preserving national currencies could further increase business risks for any company that exports goods or services, or which competes with imports, especially those in the manufacturing sector, with long-lived factories. The United Kingdom is an important component of international trade relations, and therefore changes in the level of the exchange rate of the British pound endanger the overall condition of the British economy. This challenge is now heightened even more because of the existence of two large currency blocs: the U.S. dollar bloc and the euro bloc. All British companies must face the problem of trading in those two currencies, a problem that is connected with the risks of exchange rates. With the high value of the pound, the profitability of British exports is low, which causes higher inflows of continental imported goods to the British Isles.

However, one must point out that nowadays exchange rate risk is not a dramatic problem for the financial and trade sectors (in comparison to manufacturing companies), which are the main sectors of production in the United Kingdom. Second, the common currency is not the only way to eliminate exchange rate risks - strategies such as financial hedging, contracts futures, and currency swaps can help mitigate this risk. Last but not least, demand predictions, prices of goods and services, and their quality carry much more risk than any variations connected with the volatile exchange rate of a currency. Additionally, the danger of terrorist attack should also be kept in mind.

These three aforementioned effects (elimination of transaction costs, lower volatility of exchange rate, more transparent prices) could lead to major changes in the business environment throughout Europe, making it more competitive and more productive. Likewise, for businesses, transparency of prices and the elimination of exchange rate uncertainty within the euro zone will make it easier to benchmark costs across suppliers. It will result in the rationalization of European industries, but the customer will benefit through price reductions and improved quality. ${ }^{17}$ Britain, by virtue of not having joined the third stage of the Economic and Monetary Union, has not reaped the aforementioned benefits of adopting the single currency. Transaction costs remain, and she still has higher exchange rate uncertainty as well as higher prices of goods and services in comparison to the same products on the European continent. British economists underline that the main negative consequence of Britain remaining outside the EMU is connected with lower productivity of national companies compared with firms in the euro zone. Membership in the larger European market, which resembles the U.S. market in scale, could offer a bigger area of supply, and therefore provide greater economies of scale in production. On the other hand, it is also true that, in Europe, products and producers are much more diversified than across the Atlantic, which brings more quality and price competitiveness to the market.

16 Richard Layard, Willem Buiter, David Currie, Christopher Huhne, Will Hutton, Peter Kenen, Robert Mundell, and Adair Turner, The Case for the Euro (London: Britain in Europe Campaign, Ltd., 2000), 4.

17 David Currie, "The Pros and Cons," HM Treasury (June 1997): 14. 


\section{Foreign Investment}

Another negative aspect of non-participation in the euro zone is linked with inflows of FDI to the British Isles. Many foreign investors use Britain as a base for their operations in Europe. Since joining the organization in 1973, the share of foreign projects in the United Kingdom has risen to 26 percent of all foreign direct investment coming to the British Isles. It ranks first among the EU member states, having received about 30 percent of all inward investment coming to the European Union since the early 1990s. At the turn of 2006, foreign investors provided more than 35 percent of British gross exports. Nevertheless, Britain's share of new foreign investment projects has been falling after the introduction of the common currency in continental Europe. Hence, elimination of the exchange rate risk would lead to a better calculation basis for trade and investment in the British Isles. Then the country could become an even more attractive location for FDI.

Since the introduction of the single currency, the British share of foreign investment in Europe has fallen significantly. In 1998, the country drew 28 percent of new European investment. In 2000, the level fell to 26 percent, and in 2001 it was down to just 19 percent. Moreover, some Japanese car companies have threatened to withdraw their factories from the United Kingdom if the country does not join the currency union (but, on the other hand, inward investment from Japan is only about 5 percent of the total volume of FDI). Nevertheless, the British market is very popular among foreign investors because of the fast and easy access it offers to the European market, its skilled workforce, a friendly business environment, low corporate taxes, and the use of the English language. ${ }^{18}$

It must also be stressed that the common currency influences capital markets, increasing currency liquidity and returns on capital. Moreover, the euro diminishes the costs of gaining and keeping capital on bank accounts as global financial markets integrate and become more liquid as well. The capital that is flowing into the market from outside could pursue the highest-return investment opportunities across the whole of the euro zone. The pressure on management to perform would increase, stimulating productivity growth. Such an effect would not be achieved without a currency union, since long-term exchange risks are very difficult to hedge, especially for returns on equity. Thus, the power of the market could allocate the capital effectively. A company with potential revenue streams could design its business system and invest capital on a maximum efficiency basis, and therefore achieve large productivity improvements. There would be no need to maintain branches of production in different countries to gain the best performance and the highest return on capital. However, the United Kingdom would not benefit from introducing the euro in terms of more liquid markets (e.g., government bond markets) and more instruments (e.g., creation of a large corporate bond market). ${ }^{19}$

\section{Economic Policy}

The area of economic policy, however, appears to offer more positive consequences for Great Britain from non-participation in the euro zone. Perhaps the most important of these

${ }^{18}$ G. Bishop \& D. Hiller, "News Analysis: Has Britain Passed the Treasury's Tests for Joining the Euro?" The Independent (3 May 2002).

19 R. Layard, et al., The Case for the Euro, 14-17. 
benefits is the ability of the British authorities to implement appropriate economic policies for the country in times of turbulence in the national economy. It must also be stressed that the EMU members are not moving in step. Paradoxically, and in contrast to common belief, different growth trends might be strengthened by a common monetary policy, so that a currency union would create divergence instead of convergence. There are already signs of tensions within the EMU due to different growth conditions, since a common monetary policy in no way implies a common inflation rate. Inflation has been much higher in countries leading the growth league, such as the Netherlands, Portugal, and Ireland, while Germany has had the lowest inflation rate. Given the common nominal key rate, the fast growing/high inflation countries should enjoy a higher short-term real interest rate. Bearing this in mind, the level of inflation in the United Kingdom diminished from 9.5 percent in 1990 to 3 percent in 1999, while in 2006 it was 1.9 percent. In the euro zone, the level of inflation was lower: 3.8 percent, 1.1 percent, and 1.5 percent in the respective years. Differences in the level of inflation and unemployment might show that the United Kingdom and the countries of the EMU are situated at different points of the economic cycle. Therefore, British economists argue that each country needs specific economic solutions, especially in terms of interest rates, that are tailored to fit the particular economic and financial conditions of each country. In the euro zone, the short-term interest rate is fixed by the European Central Bank, which cannot take into account all the specific features of the economies of fifteen EMU members. The lack of prior cyclical and structural convergence among all participating member states may create strains within the euro zone.

Consequently, unsynchronized business cycles and/or structural differences enlarge the effects of asymmetric external shocks (e.g., a rise in oil prices), while a unified monetary policy will be unable to satisfactorily meet the needs of all economies, concentrating upon the "average" member state and pursuing a so-called "one-size-fits-all monetary policy," as it is likely to do. Thus, incorrectly set interest rates may damage individual economies, increasing their initial misfortunes rather than moderating them. The Commission of the House of Lords on the European Union concluded, "common monetary policy ... which should fit everyone, may not be good for anybody." ${ }^{20}$ All in all, outside the EMU, in an event of any economic crisis, the United Kingdom can pursue its own, independent fiscal and monetary policies, which could help her to overcome the crisis using tools created specifically for her. The United Kingdom could surmount any emerging economic crisis in the British economy by setting interest rates according to her domestic economic circumstances.

Another positive consequence for the United Kingdom of not being a member of the euro zone is a possibility to abstain from plans focused on the centralization of fiscal policy in the European Union. This is a politically sensitive issue, since a significant part of the British population is suspicious of the idea of further steps towards a federal Europe, and common fiscal policy is a definite step towards such status. Monetary policy may be perceived as a technical problem, but matters such as taxes, transfers, and central government activities are far too sensitive for national parliaments to release from their grip. The British prefer to stay outside the European economic integration process because they are

20 “Wielka Brytania: o wspólnej walucie,” Rzeczpospolita (9 December 2000). 
unconvinced about the benefits of political integration, and are dubious regarding the creation of a federal state on the European continent. ${ }^{21}$

It is, however, advisable for the U.K. to still consider the possibility of becoming a member of the EMU, because accepting the common currency could help in synchronizing different economic cycles between the United Kingdom and members of the euro zone. Moreover, membership in the euro zone could facilitate the restructuring and modernizing of many sectors of the British economy, leading to higher productivity and higher competitiveness. Furthermore, as was mentioned above, one of the most important factors behind cyclical convergence is the increasing European integration of the British economy 54 percent of exports and 47 percent of imports are traded with the euro zone. Hence, joining the EMU would bring about a permanent, reliable exchange rate among the main British trading partners from Europe, which would contribute to even more similarity with the EMU member states. It is also worth mentioning that nowadays it is difficult to pursue completely independent economic and monetary policies, given the level of interdependence that characterizes the world of today.

Finally, by entering the euro zone, the United Kingdom would be the second largest economy in the union, behind Germany but more or less equal to France, and would therefore be a substantial player, one of major importance to the European Central Bank. Moreover, there already are "one-size-fits-all" interest rates in the United Kingdom. No single interest rate would ever be ideal for all parts of Britain, whether set by the Bank of England or elsewhere. Currently, the monetary policy conducted by the Bank of England does not always fit the economic demands of different areas of the British Isles. Different industries and regions within the nation's borders require different interest rates. For instance, manufacturing exporters in northern England have complained that rates have been set that favor the southeastern part of the country. ${ }^{22}$

\section{The British Housing Market}

Yet another positive consequence of non-participation in the third stage of the EMU is connected with the British mortgage market. The British financial system is based on specific rules. In the United Kingdom, there are floating credit rates, while on the continent they are stable. Therefore, the amount of credit and mortgage debt taken on by British households is higher than in the rest of the EU member states. As a result, the private financial sector in Britain is more susceptible to changes in interest rates than in other European countries, since a higher proportion of mortgage debt is denominated in flexible rather than fixed interest rate stock. ${ }^{23}$ The aggregate mortgage debt is 60 percent of GDP in Britain, but only 40 percent in Germany, 25 percent in France, and 10 percent in Italy. The interest rates paid on these lower levels of personal debt are also less flexible on the continent than in the United Kingdom. The variable rate liabilities of the personal sector

21 Nils Gottfries, "Why is Sweden not in EMU?," Current Sweden 435 (Swedish Institute, January 2002): 5 .

22 See www.euro.gov.uk.

23 Ben Patterson, "EMU and the United Kingdom," Task Force on Economic and Monetary Union, European Parliament, PE 166.059/rev.3 (April 1998), 19-20. 


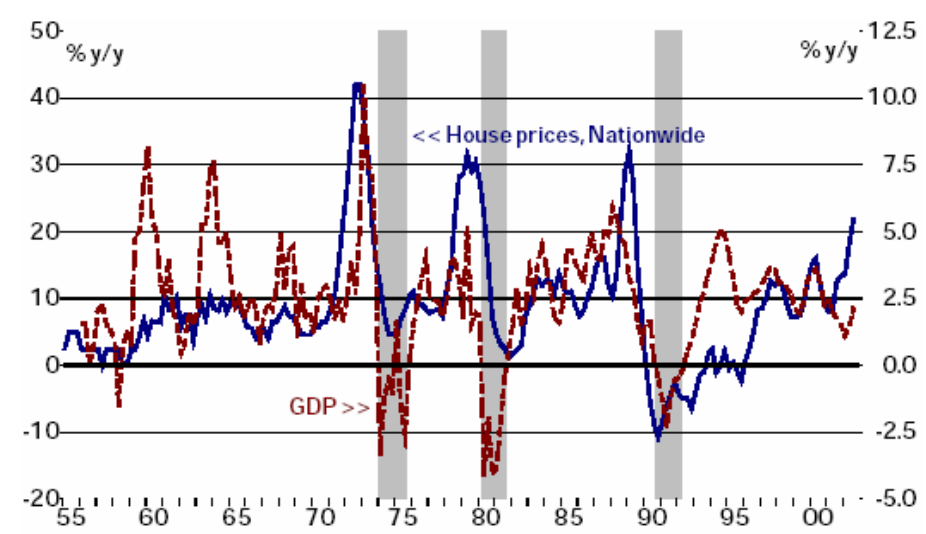

Figure 3: Prices of Houses in the United Kingdom ${ }^{24}$

total 64 percent of the British GDP. ${ }^{25}$ Consequently, if the ECB varied interest rates in order to stimulate or restrain average EMU economic activity, the United Kingdom would be disproportionately impacted by these corrective measures, causing the economy to diverge further from the EMU average. Thus, a unified monetary policy would be likely to create fluctuating boom-and-bust cycles in the British economy, rather than a smooth and sustainable rate of economic development.

Moreover, the housing market in Great Britain determines the wealth of the homeowners, because it is very common for homeowners in Britain to take a mortgage against the equity in their property. The British housing market is very liberalized and competitive, so the country experiences significant differences in the level of individual mortgage credits. The last decade has seen an increase in property prices in the British Isles, which was justified by the relatively small supply of housing.

Rising home prices and short-term investing periods in Great Britain are the best evidence that monetary policy is critically important for Britain. Introduction of the European interest rate could be disastrous for the British economy, since the last three recessions in Great Britain were caused by dangerous increases in house prices. Currently, property prices are still on the rise, and on these grounds it would be advisable for the United Kingdom to remain outside the euro zone. Otherwise, lower European interest rates could create additional inflation, and the British economy might become overheated.

\section{London's Global Role}

Britain's non-participation in the euro zone has a positive effect on London's role as a worldwide financial center, which is characterized by its unique international orientation. London is the most international of the leading financial centers, and has a dominant share of many global markets. The London Stock Exchange has a greater turnover than all other

24 Source: Danske Bank.

25 Walter Eltis, "British EMU Membership Would Create Instability and Destroy Employment," in The Impact of the Euro, eds. Baimbridge, et al., 140. 
European countries combined. The London foreign exchange market is the largest in the world, with a daily turnover of 776 billion pounds sterling in December 2006. In 2007, there were 252 foreign banks in London, two-thirds of which were based in non-EU countries, more than in any other city in the world, and the London Stock Exchange has 649 foreign companies registered. The competitive strength of the City has traditionally rested on a number of factors: a large pool of financial expertise, a wide range of ancillary support services, light regulation of securities trading, a favorable tax regime for expatriates moving to London, language, and location in a major political and cultural European center. Moreover, high volumes of trade allow London to offer competitive terms for trading. London's pre-eminence has also made it easier to attract first-rate financial experts; the availability of this expertise makes London attractive both for trading and locating an operation.

British participation in the euro zone would certainly undermine this leading international role of the City of London by imposing restrictions on its markets and institutions, and, generally, by submitting the City to tight control by the ECB. Moreover, the EMU could affect the City's international predominance by eliminating the possibility for London to develop as the main offshore market in Euros or in euro-denominated assets. This activity, in case of British participation in the EMU, would certainly be taken over by one of its major global competitors. Finally, it is necessary to take into consideration the domestic economic consequences of joining a monetary union. These are usually included in the expression a "loss of sovereignty," but, in the case of the City of London, it has the clear-cut implication that the nation would lose the ability to influence domestic monetary and exchange rate policies, which could be interpreted as a loss of domestic political power. $^{26}$

Nevertheless, since the success of the City of London has always been linked to its ability to adapt to the changing environment, its markets and institutions would certainly be able to make the most of business opportunities coming from the establishment of a single currency area, even while remaining outside it. Evidently the supremacy of the City of London has not been damaged even though the United Kingdom has remained outside the euro zone. The fact that much of the business conducted in the City is independent of whether or not the United Kingdom is part of the single currency area underlines the London market's superior efficiency, as does London's greater market share. This could be weakened if banking regulations drawn up in Frankfurt reflected continental rather than British interests. Moreover, the City would be disadvantaged by British non-participation in the euro zone if European exchanges and markets could merge; new debt and currency instruments could become the preferred medium of trade and hedging activity. However,

${ }^{26}$ Laila Talani, "Who Wins and Who Loses in the City of London from the Establishment of European Monetary Union," in After the Euro. Shaping Institutions for Governance in the Wake of European Monetary Union, ed. Colin Crouch (Oxford: Oxford University Press, 2000), 130-31. 
the financial services sector still produces about 18 percent of the country's GDP, and the City of London remains very competitive, even without participation in the euro zone. ${ }^{27}$

On the other hand, there are at least two negative implications of Britain's non-participation in the EMU for the City of London. First, there is less British influence on shaping EU financial markets legislation. Second, the financial expertise of the City is not made available to the euro financial markets. Consequently, the inclusion of the large British financial market in the EMU would contribute to elevating the global position of the euro zone in international financial relations. ${ }^{28}$ It must be stressed, however, that if the United Kingdom were inside the euro area, the offshore markets would necessarily be located outside the City of London, and possibly in one of its international rival finance centers, New York or Tokyo. This makes for a very strong case against British membership in the euro zone. Remaining a non-participant could even enable London to become the center for euro-euro deposit trading, as it would become a natural location for excess liquidity seeking to escape the onerous ECB regime. Moreover, its position as an international money market center-namely its dominant position in the already established Eurocurrency and Eurocommercial paper markets - would not be threatened. ${ }^{29}$

\section{Balance of Payments}

Last but not least, membership in the euro zone is connected with the United Kingdom, France, Germany, and the other EU member states all having the same currency. In consequence, each of them would no longer have a balance of payments deficit with the others. In fact, however, the deficit would still exist. More money would be going out of Britain than was coming in. What would change is that this deficit would no longer be recorded, and it would no longer be seen as the duty of the government to do anything about it. So, to that extent, the underlying problem would actually be made worse. This real imbalance in economic activity would have to be balanced instead by falling relative income and wealth in Britain, which would continue until the country could no longer afford the imports that were causing the problem. People would be made poorer; jobs would be lost. However, as the economy declined, less would be bought from domestic firms as well, so some of these will be forced out of business. ${ }^{30}$

\section{Political Consequences of Staying Outside the Economic and Monetary Union}

Participating in the third phase of the EMU and agreeing on the introduction of the euro would have considerable political consequences for the United Kingdom. It would bring

27 Jay H. Bryson, Special Report: Prospects for EMU Expansion, Wachovia Securities, Economic Group International (March 2002), 2-3. To read more about the economic situation of the City of London, see Timothy Edmonds, The Euro-Zone: Year One, Research Paper 00/34, Economic Policy and Statistics Section, House of Commons Library (March 2000), 23-26; Talani, "Who Wins and Who Loses in the City of London," 113-37.

30 J. Michie, "The Economic Consequences of EMU in Britain," in The Impact of the Euro, eds. Baimbridge, et al., 51. 
about a strengthening of the bargaining position of the country within the European Union as well as in the area of international economic and financial relations, which would consequently have implications for Britain's political situation, both at home and abroad.

Entering the euro zone would increase the influence of Great Britain in Europe and in the world. Joining the EMU will not mean passing laws that will directly affect and limit the country's powers of action (such powers already exist whether the country joins the euro zone or not). However, being inside the union would enable her to have stronger influence over how these powers are used. Furthermore, membership in the European Central Bank would give Britain a heightened level of influence on the European business cycle, which is now regarded as the main obstacle in the way of Britain's membership in the EMU by national politicians and economists. Being a member of the euro zone would give the country more influence outside the European continent as well.

Likewise, the Economic and Monetary Union is already well entrenched, counting fifteen countries as members. This is a greater number than many had thought would be the case nine years ago. The presence of this larger number of states is due partly to the fact that convergence regarding inflation, interest rates, and budget deficits proceeded faster than many had expected, and that the convergence criteria were interpreted liberally. As the EMU grows in size, the political costs for Britain of remaining outside grow as well. It will unavoidably further reduce and marginalize her political influence in Europe. ${ }^{31}$

However, the common currency is generally thought to represent an additional step toward a full political union. The commitment of a number of key EU member governments to further political integration suggest that over time the EMU could indeed favor federalism in Europe. For Great Britain - which is hostile to any notions of closer cooperation in Europe, not to mention federal solutions-joining the EMU is therefore partly a decision that leads toward joining the United States of Europe. ${ }^{32}$

\section{Social Consequences of Staying Outside the Economic and Monetary Union}

Great Britain has not been defeated in a war for centuries, primarily on account of being an island. In the absence of invasion or defeat, Britain "felt no need to exorcise history." The "Dunkirk Spirit" and the struggle of the Battle of Britain shaped later public attitudes, and a strong sense of nationhood and reinforced sovereignty continue to be core assumptions in policy making. ${ }^{33}$ Therefore, British society was convinced of the influential position of their home country both in Europe and in the world. The British did not trust European nations, and regarded the Continent as the main source of the conflicts and disturbances in international relations that had drawn Britain in over the past century. ${ }^{34}$ Furthermore, citizens of the United Kingdom "identified more with the white settler population of Australia, Canada, New Zealand, and South Africa than with the peoples of France, Ger-

31 Lars E. O. Svensson, "Sweden and the Euro," Briefing Paper for the Committee on Economic and Monetary Affairs of the European Parliament for the quarterly dialogue with the President of the European Central Bank (January 2002), 2.

32 David Currie, "The Pros and Cons," 3.

33 Kenneth Dyson and Kevin Featherstone, The Road to Maastricht: Negotiating Economic and Monetary Union (Oxford: Oxford University Press, 1999), 558.

34 John Kendle, Federal Britain: A History (London: Routledge, 1997), 155. 
many, the Low Countries, and Italy." ${ }^{, 35}$ British inhabitants were convinced about the necessity of a special relationship with the U.S. as the main source of peace on the continent, and they were opposed to ideas of closer European cooperation in that context. This cautious and critical approach is still present today, and hence the British nation is the least supportive of the European Union. The British are not only "Euro-skeptics," but also "EUskeptics" as well. There is a kind of a psychological barrier, according to which British citizens consider any European proposal more as dangerous than profitable.

Bearing this in mind, one may easily understand why the United Kingdom prefers to keep the processes of European cooperation on the governmental level, being rather unwilling to create common policies in different spheres of activity. Andrew Moravscik, in his book The Choice for Europe: Social Purpose and State Power from Messina to Maastricht, argues that British politicians were in favor of introducing the free flow of goods, services, workers, and capital, as well as creating a common market, because such steps might have improved British competitiveness, along with restructuring and modernizing the British economy. From the political point of view, membership in the EEC could have strengthened Britain's international position both in Europe and in the world. On the other hand, the development of the European Security and Defense Policy in the 1990s, along with plans to introduce the common currency, were perceived as attacks on British sovereignty. British politicians warn that bestowing new powers of action on Brussels may result in depriving British citizens of the ability to make decisions that could have a direct impact on their life. Consequently, the British government regards joining the euro zone as contributing to a loss of national sovereignty and political independence.

Staying outside the euro zone would also diminish uncomfortable feelings regarding the phenomenon known as "social dumping" that might arise after accepting the common currency. "Social dumping" refers to the export of goods from a country with weak or poorly enforced labor standards (where a manufacturer's costs are artificially lower) to a country with higher labor standards (and thus higher labor costs). Opponents of the euro indicate that, in cases of economic crisis, EMU members would be trying to compete with each other on reduction of labor costs, restraining workers' social rights at the same time-e.g., by controlling working hours or types of work contracts. ${ }^{36}$

There are other significant social consequences following Great Britain's decision to opt out of the third stage of the EMU. Up to 3.5 million British jobs depend on exports to the European Union, nearly 2 million of which are in manufacturing, and almost half a million in banking, finance, and insurance. Foreign investors, who usually come to Britain to gain an improved entrance into the single European market, employ around 25 percent of the total number of manufacturing workers. This is an issue tightly connected with currency volatility. The overall unemployment rate in the United Kingdom is low (around 5 percent for the last twenty-six years), but jobs have been lost in sectors that are exposed to the volatility of the pound that results from staying outside the euro zone. Since the launch of the euro, currency volatility was a factor in an estimated 115,000 manufacturing job

35 Stephen George, Politics and Policy in the European Union (Oxford: Oxford University Press, 1996), 133.

${ }^{36}$ Leokadia Oręziak, Euro-nowy pieniadz (Warsaw: Wydawnictwo Naukowe PWN, 1999), 40-41. 
losses, which originated from significant reductions in British firms' ability to compete in export markets due to the strength of the pound. From this point of view, it would be advisable for the United Kingdom to join the EMU. ${ }^{37}$

\section{What Does the Future Hold?}

Economists say that, for a medium-sized country like Great Britain, it is not beneficial to maintain a separate currency. The United Kingdom is too involved in international trade, and therefore is not able to neglect her interest rates (as, for example, the U.S. can). Nowadays Britain seems to be caught between two large currency blocs; only by joining the euro zone can the country protect herself against the danger of exchange rate fluctuations. Such a possibility endangers investments, and deters medium-sized companies from expanding abroad. Furthermore, currency fluctuations divert management attention toward exchange rate risks instead of to preparations for higher productivity, lower costs, and improved quality. It is impossible to avoid such perils, especially for firms that invest abroad or produce goods and services to be sold in different European countries in uncertain quantities and on uncertain prices over many years. They simply cannot maintain such risks for a long period of time.

However, opponents of the integration process on the European continent underline that economic integration is not profitable for the United Kingdom. The continental model is based on strong intervention in the labor market, high taxes, and substantial social assistance programs. As a result, continental economies are characterized by worse economic indices than the open British national economy. On average, in the last ten years, the annual real increase in economic growth rate per capita in the biggest EMU member states (Germany, France, Italy) was about 1.5 percent of GDP, while in Great Britain it was almost 2.6 percent of GDP. This means that the British economy is larger by almost 12 percent in comparison to those of her continental neighbors than it was ten years ago. With this in mind, many British economists point out that the United Kingdom will be able to maintain her economic superiority only if she casts away European models of economic management, including membership in the third stage of the EMU. ${ }^{38}$

The British see their home country as a global investor and trader whose interests are only partially located in Europe. To gain the full benefits of its unique position in the global marketplace that has been developed over the last two centuries, Great Britain needs the ability to restrict the negative impacts of an economic policy that do not suit her interests. Corporate and intervention policies in the other EU member states are seen as restricting Britain's ability to function well, and therefore the United Kingdom must emancipate herself from their negative impact. British politicians and economists underline that the European Union must be an association of traders. On the other hand, entering the euro zone is the logical next step from the creation of the common market. Without a common currency, the common market is not complete, and it is not possible to acquire all the benefits that would accrue from the creation of a common economic space in Europe. The conclusion is that if the common market is good for Great Britain, then the common cur-

\footnotetext{
37 See www.euro.gov.uk.

38 Record, "Europe is Dragging Britain into the Mire."
} 
rency must also be good for Great Britain. Not being a member of the EMU has a negative impact on British companies, and could diminish Britain's attractiveness to foreign investors. $^{39}$

Those who wish for the United Kingdom to remain outside the euro zone stress that the British government conducts its own policy of economic development, which regulates and stimulates economic functioning. Such a policy is complementary and subsidiary to the market mechanisms, and therefore takes part in sustaining profitable economic conditions for companies and for gaining long-term competitiveness in harmony with existing policies and social instruments. In consequence, there is a model of an advanced economy based on information technology and knowledge, stimulating changes in manufacturing structures, which gives companies the primary role in driving the nation's new strategic position in the global economy, concentrating on the so-called dynamic competitiveness factors (innovation, quality control and production certification, research and development, production differentiation, economies of scale and enlargement of production, and policies relating to marketing and intellectual property). ${ }^{40}$

The main positive consequence deriving from Britain's non-participation in the EMU is preserving the nation's ability to conduct autonomous economic policy. By maintaining the pound sterling, Great Britain keeps hold of the main levers of stabilization policy (e.g., interest rates, taxes), according to which the government is able to guide the development of the national economy. Therefore, the main problem with the euro is centered on the decision to turn over control of the British economy to the European Central Bank - an unknown supranational institution. British politicians are afraid that entering the euro zone would imply the return of some form of economic regime that would destroy the economic framework that was created by the Conservatives in 1979 and continued by the Labour Party in the 1990s and 2000s. This system is characterized by low taxes, an effective labor market, privatization, and a high degree of market deregulation. If Great Britain decided to join the euro zone, the benefits of the aforementioned system would be lost. ${ }^{41}$ On the other hand, this is the most common argument presented by proponents of macroeconomic stabilization, because it removes the euro from the realm of national politics, and makes it resistant to pressure from the government side.

\section{Conclusion}

Nobody can predict for certain the economic impact on the United Kingdom of joining the third stage of EMU. However, remaining outside the euro zone is not a secure option for Great Britain. It is, however, worth mentioning the costs of delaying a decision on entering the EMU. The existing level of diversification of foreign investments taking advantage of the euro zone shows that it will be hard for Great Britain to maintain the status quo. The

39 Kenneth Dyson, European States and the Euro: Europeanization, Variation, and Convergence (Oxford: Oxford University Press, 2002), 110-11.

40 Phillipp M. Hildebrand, "Inside Europe, Outside EMU: Lessons and Outlook," presentation to the Swiss-British Economic Chamber of Commerce, Geneva (24 April 2004); and "Lustre Lost," The Economist (25 March 2006).

41 Dyson, European States and the Euro, 109-10. 
United Kingdom is indeed an island, but not in economic terms. The common currency has positive effects in trade creation, higher investment rates, and competitiveness among the EMU members. Up to now, the common currency has not yet damaged the British economy. But it is advisable for the United Kingdom to join the euro zone to reap all the profits connected with the introduction of the common currency. ${ }^{42}$

${ }^{42}$ Katinka Barysch, Britain and the Euro: How to Reap the Benefits, Policy Brief (London: Centre for European Reform, June 2003), 7. 


\section{Bibliography}

Ahearne, Alan, and Jean Pisani-Ferry. "The Euro: Only for the Agile." In Bruegel Policy Brief., 2006.

Barysch, Katinka. "Britain and the Euro: How to Reap the Benefits." In Policy Brief . London: Centre for European Reform, 2003.

Bishop, G., and D. Hiller. "News Analysis: Has Britain Passed the Treasury's Tests for Joining the Euro?" The Independent (2002).

Currie, David. "EMU: Threats and Opportunities for Companies and National Economies." In The Impact of the Euro. London: Palgrave Macmillan, 2000.

Currie, David. "The Pros and Cons." In HM Treasury ., 1997.

Dyson, Kenneth, and Kevin Featherstone. The Road to Maastricht: Negotiating Economic and Monetary Union. Oxford: Oxford University Press, 1999.

Dyson, Kenneth. European States and the Euro: Europeanization, Variation, and Convergence . Oxford: Oxford University Press, 2002.

Fratianni, Michele, and Jurgen von Hagen. The European Monetary System and European Monetary Union . Boulder, CO: Westview Press, 1992.

George, Stephen. Politics and Policy in the European Union. Oxford: Oxford University Press, 1996.

Gottfries, Nils. "Why is Sweden not in EMU?" Current Sweden 435 (2002).

Gradziuk, Artur, and Katarzyna Sochacka. "Zagadnienie integracji walutowej w Unii Europejskiej na przykładzie Danii, Szwecji i Wielkiej Brytanii." Biuletyn PISM 70 (2002).

Kendle, John. Federal Britain: A History . London: Routledge, 1997.

Layard, Richard, David Currie, Christopher Huhne, Will Hutton, Peter Kenen, Robert Mundell, Adair Turner, and Willem Buiter. The Case for the Euro. London: Britain in Europe Campaign, Ltd., 2000.

Oręziak, Leokadia. Euro - nowy pieniadz . Warsaw: Wydawnictwo Naukowe PWN, 1999.

Padoa-Schioppa, Tomasso. The Road to Monetary Union in Europe: The Emperor, the Kings, and the Genies . Oxford: Oxford University Press, 2000.

Record, Neil. "Europe is Dragging Britain into the Mire." Financial Times (2005).

Talani, Laila. "Who Wins and Who Loses in the City of London from the Establishment of Euro-pean Monetary Union." In After the Euro. Shaping Institutions for 


\section{THE QUARTERLY JOURNAL}

Governance in the Wake of European Monetary Union. Oxford: Oxford University Press, 2000.

Tavlas, George S. "Benefits and Costs of Entering the Eurozone." Cato Journal 24 (2004): 89-106. 